\title{
Characterization of sex with animals in Córdoba, Colombia. An Exploratory study
}

Óscar Adolfo Medina-Pérez', Liliana Marcela García-Vega', Jean Paulina Villard Plaza", Juan Carlos Ortiz Valencia"

I Universidad Nacional Abierta y a Distancia -UNAD-.

II Independent researcher.

Correspondence address:

Oscar Adolfo Medina-Pérez

Escuela de Ciencias Sociales, Artes y Humanidades -ECSAH-

Universidad Nacional Abierta y a Distancia -UNAD-

Cra 45 \# 55-19 Medellín - Colombia

Email: oscar.medina@unad.edu.co 


\section{Abstract}

Introduction: Sex with animals is a male practice with a social acceptance in many areas of the Colombian Atlantic coast; however, this behavior has been little studied. The aim of this study was to characterize the practice of sex with animals in a group of men living in Cordoba department, Colombia.

Methods: descriptive quantitative study was made. Forty-seven adults were interviewed. The information was collected through a survey which asked about sociodemographic aspects, characteristics and beliefs around the behavior.

Results: Total participants knew about the practice, $68,1 \%$ stated to have had it and they said it happened between the ages of 7 and 30 years old, for an average time of seven years gap; $65,6 \%$ had it in presence of friends and relatives. $87,6 \%$ said the practice feels really good at the first time; $35,6 \%$ stated it was a beneficial practice and $37,5 \%$ said they would like their sons to experience it.

Conclusion: Having sex with animals is a social accepted behavior and it is thought to be positive since it helps the correct psychosexual development and it prevents other behaviors, not culturally accepted, such as drug use or homosexuality.

Keywords: Bestiality; Colombia; sexual behavior; sexuality; Zoophilia.

\section{Introduction}

The beginning of the sexual life of children and male teenagers of the Colombian Atlantic coast may be with animals, activity socially accepted in the area $(1,2)$, and even recommended by their equals and adults, since the belief of having sex with female donkeys (female donkeys is preferred animal to have sex with, though it may also be with other quadruped animals such as male donkeys, mares, pigs, mules and even birds like hens and turkeys) is important to obtain the correct psychosexual development $(1,3)$ and it prevents other behaviors not culturally accepted such as drug use or homosexuality $(4,5)$.

As other researchers have said, in spite of the singularity of the behavior, little research has been accomplished (6). Today we know, it has a high prevalence in the region because in some researches about sexual behaviors the question "have you had sex with animals?" was included. Like this, one research in 1985 
by Barranquilla university students showed that $42,0 \%$ of the single men and $59,0 \%$ of the married men had sex with animals (7); another research in 1990 in the same city showed that $12,0 \%$ of men having a couple had sex with animals (8). In 1999, it was reported a prevalence of the practice of $12,3 \%$ among students of eleventh grade in Cartagena; when the reason was asked, $4,7 \%$ said for curiosity, $4,3 \%$ said it was proposed to them to do it, and the rest said they saw it and they wanted to do it (9).

In the research made, only one work has been found which studies exclusively the topic with a scientific view. This work was a presented in a psychiatrists' congress in Colombia in 1982, text reproduced again by Cordoba history academy journal in 1986 (1). Authors made clear the mentioned behavior is part of the psychosexual develop of Cordoba and Sucre savanna, it is a normal behavior, which appears at the age of $10-11$ years old or before, and it is expected to end at the age of $18-20$ years old. He additionally says the practice is eminently in group (1).

The aim of this study was to characterize sexual practices with animals in a group of men living in the department of Cordoba, Colombia.

\section{Materials and methods}

Design: the research was a quantitative descriptive study design.

Participants: Convenience sampling was used. The people participating in the research are living in San Pelayo, Cordoba. The following inclusion criteria were kept in mind: a) they must be adults, b) they must be men, c) their parents must be from the region - This criteria was included because intercourse with animals, in the Colombian Caribbean zone, is not generally considered as inappropriate, and relatives or friends may even make pressure so the practice takes place; then, people from the area with parents from other regions may not have the same pressure to do it and d) they must have lived their first fifteen years in any place of the Colombian Atlantic coast -since it is expected that this practice starts before the fifteen years old-. Two exclusion criteria were kept in mind: a) those who did not have any interest about participating in the research and $b$ ) those who evidently showed at the initial conversation they did not have the minimal cognitive condition to respond a survey.

The questionnaire: A survey was designed which collected sociodemographic information and characteristics of the intercourse with animals, such as: age 
of onset and completion, behaviors before and during the sexual act, and beliefs around the practice were also asked.

Procedure: The survey participants were contacted in the urban area of the municipality. The goals of the researchers were explained right after the greeting. It was made clear that participation was voluntary, that there would be no financial compensation for participation, the participants could leave the survey at any moment and the information received was going to be completely confidential. The questionnaire was made individually, it took an average of thirty minutes and it took only one session. The information was tabulated in excel after finishing the surveys. In the same program, the analysis of results were made.

\section{Results}

Forty seven adults in total answered the survey. $100 \%$ said they knew the practice of having sex with animals existed. $68,1 \%$ (32 adults) stated having had sex with animals at some point of their lives.

Examining those who did practice it, was found that the onset age ranged between 6 and 14 years old (the average is 9,7 years old) and the ages of completion the practice was between 12 and 30 years old (the average is 16,7 years old) On average, they had sexual practices with animals for 7 years. $65,6 \%$ stated they had it in presence of friends and relatives. $53,1 \%$ admitted there was not a leader who set the meetings, $65,6 \%$ said they did not have an instruction about how to do it, 40,6\% stated the period the most they practiced it, was during several times in a month. None of them used condom or any method to prevent sickness or diseases. Table 1. 
Table 1. Demographic characteristics of a men group from San Pelayo, Cordoba which have had sexual contact with animals.

\begin{tabular}{|c|c|c|c|c|c|c|}
\hline \multirow{2}{*}{ Characteristics } & \multirow{2}{*}{$\begin{array}{c}30-44 \\
N\end{array}$} & \multirow[b]{2}{*}{$\%$} & \multicolumn{2}{|l|}{$45-59$} & \multirow{2}{*}{ Total } & \multirow[b]{2}{*}{$\%$} \\
\hline & & & & $\%$ & & \\
\hline \multicolumn{7}{|l|}{ Have you ever practiced it? } \\
\hline Yes & 18 & 58,1 & 14 & 87,5 & 32 & 68,1 \\
\hline No & 13 & 41,9 & 2 & 12,5 & 15 & 31,9 \\
\hline \multicolumn{7}{|l|}{ Starting Age } \\
\hline Between 6 y 8 years old & 5 & 27,8 & 6 & 42,9 & 11 & 34,4 \\
\hline Between 9 y 11 years old & 7 & 38,9 & 8 & 57,1 & 15 & 46,9 \\
\hline \multirow{2}{*}{\multicolumn{7}{|c|}{ Last time age }} \\
\hline & & & & & & \\
\hline Between 10 y 13 ye & 4 & 22,2 & 1 & 7,1 & 5 & 15,6 \\
\hline Betw & 11 & 61,1 & 6 & 42,9 & 17 & 53,1 \\
\hline 8 y 20 & 2 & 11,1 & 6 & 42,9 & 10 & 25,0 \\
\hline At 30 years old & 1 & 5,6 & 1 & 7,1 & 2 & 6,3 \\
\hline \multicolumn{7}{|c|}{ Who did you normally practice it with? } \\
\hline With Friends and relatives & 9 & 50,0 & 12 & 85,7 & 21 & 65,6 \\
\hline Alone & 9 & 50,0 & 2 & 14,3 & 11 & 34,4 \\
\hline \multicolumn{7}{|c|}{$\begin{array}{l}\text { Was there a leader who programed the } \\
\text { meetings? }\end{array}$} \\
\hline Yes & 6 & 33,3 & 9 & 64,3 & 15 & 46,9 \\
\hline No & 12 & 66,7 & 5 & 35,7 & 17 & 53,1 \\
\hline \multicolumn{7}{|c|}{ Did somebody prompt you to do i } \\
\hline Yes & 3 & 16,7 & 8 & 57,1 & 11 & 34,4 \\
\hline & 15 & 83,3 & 6 & 42,9 & 21 & 65,6 \\
\hline \multicolumn{7}{|c|}{$\begin{array}{l}\text { How often did you practice it in the } \\
\text { period the most you did it? }\end{array}$} \\
\hline Everyday & 4 & 22,2 & 3 & 21,4 & 7 & 21,9 \\
\hline Several times a & 4 & 22,2 & 8 & 57,1 & 12 & 37,5 \\
\hline Several times a month & 10 & 55,6 & 3 & 21,4 & 13 & 40,6 \\
\hline
\end{tabular}

The $87,7 \%$ said the first time felt good or very good, $65,6 \%$ stated the experience did not make any big difference in their sexual preference, $64,5 \%$ think the practice may currently be prejudicial and $37,5 \%$ admitted they would like their sons to experience it. Table 2. 
Table 2. Characteristics and beliefs of a group of men from San Pelayo, Cordoba which have had intercourse with animals.

\begin{tabular}{|c|c|c|c|c|c|c|}
\hline \multirow[t]{2}{*}{ Characteristics } & \multirow{2}{*}{$\begin{array}{c}30-44 \\
N\end{array}$} & \multicolumn{3}{|c|}{$45-59$} & \multicolumn{2}{|l|}{ Total } \\
\hline & & $\%$ & & $\%$ & & $\%$ \\
\hline How did you feel at the first time? & & & & & & \\
\hline Scared, I had troubles & 1 & 5,6 & 1 & 7,1 & 2 & 6,3 \\
\hline I felt good, or very good & 15 & 83,4 & 13 & 92,8 & 28 & 87,6 \\
\hline I did not like it & 2 & 11,1 & & & 2 & 6,3 \\
\hline Did it change your sexual preferences? & & & & & & \\
\hline No, They did not say anything & 7 & 38,9 & 6 & 42,9 & 13 & 40,6 \\
\hline No, Other answers & 5 & 27,8 & - & - & 5 & 15,6 \\
\hline No, I already knew I was a man & 2 & 11,1 & 1 & 7,1 & 3 & 9,4 \\
\hline Yes, I felt man & 3 & 16,7 & 5 & 35,7 & 8 & 25,0 \\
\hline Yes, Other answers & 1 & 5,6 & 2 & 14,3 & 3 & 9,4 \\
\hline $\begin{array}{l}\text { What do you think about the practice in } \\
\text { this moment? Is it positive or not and } \\
\text { why? }\end{array}$ & & & & & & \\
\hline Positive, it gives sexual experience & 4 & 22,2 & 2 & 15,4 & 6 & 19,4 \\
\hline $\begin{array}{l}\text { Positive, it prevents use drugs and } \\
\text { homosexuality }\end{array}$ & 2 & 11,1 & 3 & 23,1 & 5 & 16,1 \\
\hline $\begin{array}{l}\text { Harmful, they can get any disease } \\
\text { Would you like one of your sons to do } \\
\text { it }\end{array}$ & 12 & 66,7 & 8 & 61,5 & 20 & 64,5 \\
\hline No & 12 & 66,7 & 8 & 57,1 & 20 & 62,5 \\
\hline yes, so they gain experience & 6 & 33,3 & 6 & 42,9 & 12 & 37,5 \\
\hline
\end{tabular}

\section{Discussion}

It was found that the total of the survey respondents knew about the existence of sex with animals in the region. This may be due to the social acceptance this behavior has in the Caribbean region of Colombia. Escoppetta says: "The experience of having sex with female donkeys (...) was a natural step within a culture which does not prohibit the intercourse between men and animals" (2). In fact, the usual thing is that children and adolescents comment extensively on their experiences among peers (4), and adults see this as a correct behavior. The practice is so common that, even due to the suspicion of the presence of lymphogranuloma venereum, the physicians of the region asked in the interview if there was sex with animals (10).

The survey made clear that most of the survey respondents had sex with animals. Other research made in the Caribbean region of Colombia reported high prevalence of sex with animals. In 1985, a prevalence of $59,0 \%$ was 
reported (7), in 1990, a prevalence of $12,0 \%$ was reported (8). In 1999, $11,3 \%$ of the survey respondents had had sex with animals (9). Solano Berrío, in a talk presented in 1982, said: "Most of men over 25 years old in the Cordoba and Sucre savannah accept they have had any sexual relation with animals"(1). Anyway, the numbers in the Caribbean region are are much higher than those found in cities that are not part of the Caribbean region; in Cucuta, for example, the prevalence is until 1,2\% among university students (11).

The survey made also clear that most of them did it in the company of a friend or relatives. That agrees with previous researches (1), and it is verified by different sources; for instance, in the documentary realized by Ryan Duffy in Cartagena one of the survey respondents said: "Every Sunday we used to go to the river and there we had sex with the female donkeys" (3). In a research made in Sincelejo, it was stated that: "It is normal to hear the adolescents inviting one another to rent or to borrow a female donkey so they take it to a stable far from their houses to discharge their semen in it and then talk about the experience among them" (4).

Talking about the starting age, the survey showed that all of the survey respondents had their first experience with animals before the age of 14 which coincides with other researches. Suárez et al state: "Many of the sexual experiences of the men from Malambo start at 12 or 13 years old, many of them in the farms, in the stables, or in the hills. Their experiences with animals (most of them with female donkeys) which they learn how to penetrate, so they find gratification in their zoophilic practice" (12). Other source say that beginning may be in the childhood, when the children go to see their older friends or relatives having sex with the animals (5).

It was also found that most of them stop having sex with animals in their 20 s. That fact may respond to the age when the men start having sex with women (1), but there are reports which say that behavior continues after the 20s and it happens especially when the young man does not have easy access to women (2).

The survey made clear that none of the respondents used condoms when having sex with animals, This can be explained because the use of condoms in very low in the area (2), so those who have sex with animals are in high danger 
to get infections(10). There is also evidence which says that this practice may cause penis cancer $(6,13)$.

The survey made also clear that for many of the survey respondents the practice influenced positively in their future sexuality and $25 \%$ of them said they felt like a men after that, or ready to be with a woman. The same fact has been concluded in other researches $(1,4)$.

It was found that a third of those who had sex with animals would like their sons to have the experience. They suggest the act receives a positive valuation. Solano says: "when the fathers or the adults around the boy know the behavior, they think it is the beginning of their sexual life and they start speaking about it with pride and satisfaction instead of speaking about it as sick or inappropriate behavior" (1).

It was also found that third of the survey respondents think it helped them to prevent homosexuality and drug use. Data of the benefit of having sex with animals is taken from other places. One of the interviewees man by Ryan Duffy said: "Doctors recommended the female donkeys before... the female donkeys help the boys to become men" (3). In many parts, Movilla expresses similar ideas, he even thinks one of the reasons homosexuality has been increasing in the region is because the habit to have sex with animals is being lost in the adolescents (5). In Anaya's research, one of the survey respondents said the sex with animals can help to prevent craziness, because if they do not do it "their semen goes up to the head and they get crazy"(4), that is why in many stories one adult shows up recommending the practice, considering it as healthy and relating it with the masculine virility (5).

To sum up, it is important to say that big changes have been appearing in the habit, it was found for example that the interviewees with ages between 30 and 44 started the practice later and finished it earlier than those aging between 45 and 59, and the younger group tend to do it alone.

\section{Study limitations}

The authors acknowledge that the limitations of this research make it an exploratory work. In the first place, it must be taken into account that a sample was not taken, therefore the obtained findings can not be generalized to any 
population. Additionally, people under their thirties and adolescents were not interviewed. This is very important, because, as it was said at the end of the discussion, There are reasons to suspect that important changes are taking place in behavior.

Additionally, it is important to keep in mind that the survey respondents came from a small municipality, with large rural areas near to the city, a reason which could favor the sexual contact with animals. It is highly probable the prevalence of the behavior in the big cities in the area may be lower than the one in the current study.

Another fact that limits the findings of this study and forces us not to generalize its results was in the inclusion criteria that were used: it is very likely that they increased the probability of finding people who had sex with animals and hence the high prevalences found in it.

\section{Conclusions and Recommendations}

It is concluded that sex with animals in the survey respondent group is a behavior which takes place in the childhood and adolescence, that the behavior is usually made in group, and that their practice may be associated with the belief that contributes to a healthy sexuality and even to prevent behaviors that are perceived as negative, such as drug use and homosexuality.

As it is inferred about the limitations previously mentioned, it is recommended future research to be done with probabilistic sample, including adolescents, young adults and senior citizens, and taking it in big cities; only then can we discriminate the prevalence according to the population size, age group, etc; at the same time, qualitative research is also very important because it is necessary to go into detail about the belief around the practice.

Other recommendation to future research is to ask about the possible consequences on the helth of those who practice sex with animals. There are already reports of diseases associated with the practice, but the magnitude of the same is unknown.

Conflicts of Interest: The authors declare no conflict of interest. 


\section{References}

1. Solano Berrío Á. ¿ Quienes somos? Nuestras relaciones con los animales. La Rev la Acad Hist Córdoba. 1986;(3):2-5.

2. Scoppetta O. Cambios en las trayectorias de fecundidad masculina en córdoba, Colombia. Papeles Poblac [Internet]. 2009;15(62):173-99. Available from: http://bdigital.unal.edu.co/48167/7/cambiosenlastrayectoriasdefecundidadmasculina.com pressed.pdf

3. Duffy R. Asses of the caribbean [Internet]. 2012. Available from: https://www.youtube.com/watch?v=_VKWLC87Uzw\&list=PLF8PvjP14RndHZVNrxjwMK_7 WsWv2h9H6

4. Anaya Lazo LI. Comportamientos sexuales de adolescentes y jóvenes de sectores populares del municipio de Sincelejo, Sucre [Internet]. Universidad Nacional de Colombia; 2010. Available from: http://bdigital.unal.edu.co/3912/1/leydysisabelanayalazo.2010.pdf

5. Movilla Bello LE. Señor, aguánteme la burra. Multrigráficas, editor. Sincelejo; 2007. 60 p.

6. Acosta-Guevara C, Calderón-Carvajal L, Torres L, Rosselli D. Cáncer de pene y sexo con animales: a propósito de un caso. Urol Colomb [Internet]. 2017;26(2):144-7. Available from: http://www.elsevier.es/es-revista-urologia-colombiana-398-resumen-cancer-penesexo-con-animales-S0120789X16300764

7. González M. Comportamiento sexual del univenitario. Rev Latinoam Psicol [Internet]. 1985;17(1):7-56. Available from: http://www.redalyc.org/pdf/805/80517101.pdf

8. Alvarez Yguarán F, Gómez L, Acosta C, De Manzano L, De Vigna M, Vargas Rozo P. Estudio descriptivo del comportamiento sexual de hombres y mujeres que mantienen relación de pareja en Barranquilla. Investig y Desarro [Internet]. 1990;1(1):31-45. Available from: http://ciruelo.uninorte.edu.co/pdf/invest_desarrollo/1/1 Estudio descriptivo del comportamiento sexual de hombres y muj.pdf

9. Abad Iriarte L, Dueñas Castillo D. Estudio de los conocimientos y comportamientos sexuales en estudiantes de undécimo grado de un grupo de escuelas oficiales del distrito de Cartagena [Internet]. Corporación Universitaria Tecnológica de Bolívar; 1999. Available from: http://biblioteca.utb.edu.co/notas/tesis/0058096.pdf

10. Pinzón Redondo H, Causil Garcés C, Bayter Gómez C, Redondo Bermúdez C, Alvis Guzmán $\mathrm{N}$. Linfogranuloma venéreo posterior al contacto sexual con una burra: reporte de un caso en pediatría. Cartagena, Colombia. Rev Enfermedades Infecc en Pediatría [Internet]. 2012;27(102):234-6. Available from: http://www.medigraphic.com/pdfs/revenfinfped/eip2012/eip124i.pdf

11. Manosalva Quiceno M, Mendoza Rincón B, Triana Baquero R, Useche Aldana B. Conducta sexual de estudiantes universitarios de la ciudad de Cúcuta. Inf psicológicos [Internet]. 2014;14(1):129-41. Available from: http://www.redalyc.org/pdf/805/80517101.pdf

12. Suárez Ch. L, Mendivil C. CR, Vega MJ. Jovenhablajoven: una experiencia de comunicación y salud en un población del caribe colombiano. Investig Desarro [Internet]. 2004;12(1):4477. Available from: http://rcientificas.uninorte.edu.co/index.php/investigacion/article/viewArticle/1099

13. Zequi S, Guimaraes G, Matheus W, Aita G, Glina S, Guidoni LM, et al. Sex with animals (SWA): Behavioral characteristics and possible association with penile cancer. A multicenter study. J Sex Med [Internet]. 2012;9(7):1860-7. Available from: https://www.sciencedirect.com/science/article/pii/S1743609515340273 